\title{
SIKAP MAHASISWA TERHADAP BAHASA INDONESIA (STUDI KASUS DI PERGURUAN TINGGI SE-CIREBON)
}

\author{
Indrya Mulyaningsih \\ IAIN Syekh Nurjati Cirebon \\ indrya.m@gmail.com
}

\begin{abstract}
Abstrak
Banyak mahasiswa yang berusaha belajar bahasa Inggris. Hal ini tentu saja berpengaruh terhadap keberadaan bahasa Indonesia. Seiring berjalannya waktu, sangat mungkin jika bahasa Indonesia sudah jarang digunakan dan digantikan oleh bahasa asing. Penelitian ini dilakukan dari Mei sampai Oktober 2017. Adapun populasinya adalah seluruh mahasiswa berbagai perguruan tinggi di Cirebon, baik bidang umum, agama, maritim, maupun kesehatan. Sampel penelitian adalah masing-masing satu kelas dari 38 perguruan tinggi yang ada di wilayah Cirebon. Berdasarkan analisis data dapat disimpulkan bahwa mahasiswa memiliki sikap bahasa yang baik. Hal ini dibuktikan dengan pemahaman akan kaidah bahasa Indonesia yang sudah baik juga. Demikian juga pada aspek afektif. Meskipun memelajari bahasa asing, mahasiswa tetap bangga dan menggunakan bahasa Indonesia. Adapun faktor-faktor yang menyebabkan kecenderungan sikap bahasa tersebut: 1) mahasiswa menyadari peran penting bahasa Indonesia dalam pendidikan, 2) mahasiswa lebih percaya diri jika berbicara dengan menggunakan bahasa Indonesia, dan 3) mahasiswa yakin bahwa bahasa Indonesia akan tetap eksis karena banyaknya jumlah penggunanya.
\end{abstract}

Kata kunci: afektif, sikap bahasa, kognitif, konatif, psikomotor

\begin{abstract}
Many students are trying to learn English. This, of course, affects the existence of Indonesian language. As time passes, it is possible if the Indonesian language is rarely used and replaced by a foreign language. This research is conducted from May to October 2017. The population is all students of various universities in Cirebon, both general, religion, maritime, and health. The sample of research is each one class from 38 universities in Cirebon region. Based on data analysis it can be concluded that students have good language attitude. This is evidenced by the understanding of the Indonesian rules that have been good as well. Likewise on affective aspect. Despite learning foreign languages, students remain proud and speak Indonesian. The factors that cause the tendency of language attitude are: 1) the students realize the important role of Indonesian language in education, 2) the students are more confident when speaking in The Indonesian language, and 3) the students are convinced that The Indonesian language will still exist because of the large number of users .
\end{abstract}

Keyword: affective, language attitude, cognitive, conative, psychomotor

\section{A. Pendahuluan}

Keberadaan bahasa Indonesia dilindungi oleh Undang-Undang. Bahkan Peraturan

Pemerintah No. 29 Tahun 2009 khusus dibahas bahasa, bendera, dan lambang negara. 
Hal ini berarti, keberadaan serta keberlangsungan bahasa Indonesia memiliki kekuatan hukum yang jelas dan kuat. Tentu saja perlindungan ini tidak begitu saja, melainkan terdapat berbagai hal yang melatarbelakangi. Seiring kemajuan teknologi, bahasa Indonesia bukan merupakan satu-satunya bahasa yang dikuasai oleh seseorang. Kemajuan teknologi membawa pada kemudahan berkomunikasi, baik di dalam negeri maupun di luar negeri. Hal inilah yang kemudian menjadikan seseorang tidak hanya dapat berbahasa Indonesia, tetapi juga berbahasa lain. Banyak faktor yang menyebabkan seseorang ingin dan dapat berbahasa selain bahasa Indonesia.

Dalam ilmu bahasa, bahasa selain bahasa Indonesia yang berasal dari negara lain disebut bahasa asing. Saat ini, banyak tempat kursus bahasa asing, seperti bahasa Inggris, bahasa Jepang, bahasa Mandarin, dan bahasa Korea. Bahasa-bahasa asing ini sengaja dipelajari untuk membekali para tenaga kerja Indonesia yang bekerja di luar negeri. Selain itu, penguasaan terhadap bahasa asing dapat memudahkan seseorang dalam berkomunikasi di media sosial. Semakin terbuka dan mudahnya komunikasi lintas negara telah memunculkan fenomena tertentu terhadap bahasa Indonesia. Fenomena tersebut berupa semakin berkurangnya para pengguna bahasa Indonesia, terutama di kalangan pemuda atau mahasiswa. Hal ini didukung dengan adanya anggapan bahwa orang yang pandai adalah orang yang fasih berbahasa asing. Dalam hal ini adalah bahasa Inggris.

Berdasarkan hal tersebut, banyak mahasiswa yang berusaha belajar bahasa Inggris. Hal ini tentu saja berpengaruh terhadap keberadaan bahasa Indonesia. Seiring berjalannya waktu, sangat mungkin jika bahasa Indonesia sudah jarang digunakan dan digantikan oleh bahasa asing. Oleh karena itu, perlu dilakukan penelitian untuk dapat mengantisipasi hal tersebut.

Penelitian Sobara dan Ardiyani (2013) mendeskripsikan sikap berbahasa mahasiswa laki-laki dan perempuan yang ditandai oleh tiga ciri, yaitu (1) kesetiaan bahasa (language loyality), (2) kebanggaan bahasa (language pride), dan (3) kesadaran adanya norma bahasa (awareness of the norm). Penelitian ini berdesain deskriptif kualitatif yang dilaksanakan di Jurusan Sastra Jerman Fakultas Sastra Universitas Negeri Malang. Sumber datanya 10 mahasiswa laki-laki dan perempuan. Data diperoleh melalui pengamatan serta kuesioner. Adapun simpulan dari penelitian ini adalah 
kelompok responden laki-laki dan perempuan keduanya mempunyai sikap bahasa yang baik.

Penelitian Wistari, Suandi, dan Wendra (2015) mendeskripsikan sikap bahasa dilihat dari aspek (1) konatif, (2) afektif, (3) kognitif, dan (4) faktor-faktor yang memengaruhi sikap bahasa siswa program Cambridge Dyatmika School. Desain penelitian menggunakan deskriptif kualitatif dan kuantitatif. Siswa program Cambridge sebagai subjek penelitian. Data dikumpulkan menggunakan metode observasi, angket, dan wawancara. Analisis data menggunakan teknik deskriptif dengan prosedur: (1) reduksi data, (2) penyajian data, dan (3) verifikasi. Hasil penelitian menunjukkan bahwa (1) aspek konatif yang dimiliki oleh siswa Program Cambridge Dyatmika School berada pada kategori negatif; (2) aspek afektif yang dimiliki oleh siswa Program Cambridge Dyatmika School berada pada kategori kategori cukup; (3) aspek kognitif yang dimiliki oleh siswa Program Cambridge Dyatmika School terhadap bahasa Indonesia ada pada kategori positif; serta (4) faktor yang mempengaruhi siswa Program Cambridge Dyatmika School terhadap bahasa Indonesia. Faktor dari aspek konatif karena kurangnya pemahaman siswa terhadap kosakata dan kepekaan siswa. Faktor dari aspek afektif karena emosional siswa untuk mempertahankan bahasa Indonesia. Faktor dari aspek kognitif karena lingkungan dan rasa percaya diri siswa.

Penelitian Wardani, Gosong, dan Artawan (2013) mendeskripsikan sikap bahasa yang ditunjukkan oleh siswa SMA Negeri 1 Singaraja terhadap bahasa Indonesia dilihat dari (1) aspek konatif, (2) afektif, (3) kognitif, dan (4) faktor yang menyebabkan kecenderungan sikap bahasa tersebut. Subjek penelitian ini adalah siswa SMA Negeri 1 Singaraja tahun ajaran 2012/2013. Pengumpulan data menggunakan metode observasi, samaran terbanding, angket, dan wawancara. Analisis data observasi dan wawancara dilakukan melalui tiga tahap, yaitu reduksi data, penyajian data, dan penarikan simpulan atau verifikasi. Analisis data samaran terbanding dan kuesioner secara umum melalui empat tahap, yaitu penggolongan, pengkonversian, penghitungan frekuensi, dan menentukan kecenderungan sikap bahasa siswa. Hasil penelitian menunjukkan bahwa sikap bahasa siswa SMA Negeri 1 Singaraja terhadap bahasa Indonesia dilihat dari (1) aspek konatifnya berada pada kategori negatif, (2) aspek afektifnya berada pada kategori positif, dan (3) aspek kognitifnya berada pada kategori netral. (4) Faktor-faktor yang menyebabkan kecenderungan sikap bahasa tersebut adalah faktor internal dan 
eksternal. Berdasarkan temuan tersebut, dapat disimpulkan bahwa siswa SMAN 1 Singaraja cenderung memiliki sikap bahasa yang bersifat meniga terhadap bahasa Indonesia, yang disebabkan oleh faktor internal dan eksternal.

Sikap bahasa atau language attitude merupakan tata keyakinan atau kognisi yang relatif berjangka panjang mengenai bahasa yang memberikan kecenderungan kepada seseorang untuk bereaksi dengan cara tertentu yang disenangi (Anderson dalam Chaer dan Agustina, 1995). Menurut Kridalaksana (2001), sikap bahasa merupakan posisi mental atau perasaan terhadap bahasa sendiri atau bahasa orang lain. Sikap bahasa terbagi atas positif dan negatif. Sikap positif bahasa memiliki tiga ciri, yakni 1) kesetiaan bahasa (language loyalty), 2) kebanggaan bahasa (language pride), dan 3) kesadaran adanya norma bahasa (awareness of the norm) (Garvin dan Mathiot dalam Chaer dan Agustina, 1995). Kesetiaan bahasa berarti adanya dorongan dari suatu masyarakat bahasa untuk mempertahankan bahasanya. Dalam hal ini dapat berupa pencegahan terhadap berbagai bahasa asing. Kebanggaan bahasa mendorong seseorang mengembangkan bahasanya dan menggunakannya sebagai identitas dan kesatuan masyarakat. Kesadaran adanya norma mendorong orang menggunakan bahasanya dengan cermat dan santun.

Sikap negatif bahasa merupakan kebalikan dari ketiga sikap positif tersebut. Artinya, seseorang lebih suka menggunakan bahasa selain bahasa Indonesia. Masyarakat mulai banyak yang menggunakan bahasa Inggris atau bahasa asing lainnya. Hal ini menunjukkan bahwa sikap bahasa yang dimiliki adalah negatif. Demikian pun ketika seseorang sudah tidak merasa bangga dengan bahasa Indonesia. Fenomena ini dapat ditemui terutama pada remaja yang lebih suka menggunakan bahasa Inggris dalam berkomunikasi. Sikap negatif terhadap bahasa terjadi karena tidak dimilikinya lagi gairah atau dorongan untuk mempertahankan bahasa. Banyak faktor yang menyebabkan hilangnya rasa bahasa, antara lain karena politik, ras, etnis, dan gengsi (Chaer dan Agustina, 1995).

Di Indonesia, tingkatan pendidikan dibagi dalam beberapa tingkat, yakni sekolah dasar, sekolah menengah pertama, sekolah menengah atas, dan perguruan tinggi. Perguruan tinggi merupakan tingkatan tertinggi. Tingkatan ini ditempuh setelah seseorang lulus atau menyelesaikan tingkat sekolah menengah atas. Perguruan tinggi dapat berupa akademi, politeknik, sekolah tinggi, maupun sarjana. Seseorang yang 
sedang belajar di perguruan tinggi biasa disebut dengan mahasiswa. Hal ini selaras dengan pendapat Siswoyo (2007) yang mengartikan mahasiswa sebagai individu yang sedang menuntut ilmu di perguruan tinggi atau yang setingkat dengan perguruan tinggi.

Pada umumnya, seorang mahasiswa berusia antara 18 - 25 tahun. Berdasarkan psikologi pembelajaran, usia ini dapat digolongkan pada remaja akhir dan memasuki dewasa. Pada usia ini, seseorang tinggal memantapkan pendirian hidup (Yusuf, 2012). Berikut ini ciri-ciri perkembangan seseorang pada masa remaja akhir: 1) menerima keadaan fisik, 2) memperoleh kebebasan emosional, 3) mampu bergaul, 4) menemukan model untuk identifikasi, serta 5) mengetahui dan menerima kemampuan sendiri (Gunarsa\&Gunarsa, 2001).

Secara geografis, Indonesia berada di wilayah Asia Tenggara. Dalam aktivitas perdagangan, wilayah ini menggunakan bahasa Melayu. Keberadaan bahasa Melayu berkembang di seluruh wilayah Nusantara. Pertumbuhannya dipengaruhi oleh corak budaya daerah, kegiatan politik, perdagangan, persuratkabaran, dan majalah. Bahasa Melayu menyerap kosakata dari berbagai bahasa, terutama dari bahasa Sanskerta, bahasa Persia, bahasa Arab, dan bahasa-bahasa Eropa. Perkembangan bahasa Melayu di wilayah Nusantara mempengaruhi dan mendorong tumbuhnya rasa persaudaraan dan persatuan bangsa Indonesia.

Para pemuda Indonesia yang tergabung dalam perkumpulan pergerakan secara sadar mengangkat bahasa Melayu menjadi bahasa Indonesia. Hal ini diikrarkan pada Sumpah Pemuda, 28 Oktober 1928. Para pemuda dari berbagai pelosok Nusantara berkumpul dan berikrar (1) bertumpah darah yang satu, tanah Indonesia, (2) berbangsa yang satu, bangsa Indonesia, dan (3) menjunjung bahasa persatuan, bahasa Indonesia. Peristiwa tersebut dikenal dan diperingati sebagai hari Sumpah Pemuda. Sejak itulah bahasa Indonesia dikukuhkan kedudukannya sebagai bahasa nasional.

Hal ini didukung dengan salah satu keputusan Kongres Bahasa Indonesia II tahun 1954 di Medan yang menyatakan bahwa bahasa Indonesia berasal dari bahasa Melayu. Bahkan bahasa Melayu telah digunakan di wilayah Asia Tenggara sejak abad ke-7. Hal ini dibuktikan dengan ditemukannya prasasti di Kedukan Bukit Palembang (683 M), Talang Tuwo Palembang (684 M), Kota Kapur Bangka Barat (686 M), Karang Brahi Jambi (688 M), Gandasuli Jawa Tengah (832 M), di Bogor (942 M), serta tulisan pada batu nisan di Minye Tujoh, Aceh (1380 M). Pun dapat dibuktikan dari hasil susastra 
(abad ke-16 dan ke-17), seperti Syair Hamzah Fansuri, Hikayat Raja-Raja Pasai, Sejarah Melayu, Tajussalatin, dan Bustanussalatin (Badan Pengembangan dan Pembinaan Bahasa, TT).

Pada perkembangannya, Pemerintah menguatkan keberadaan bahasa Indonesia melalui Undang-Undang Republik Indonesia No. 24 Tahun 2009 berisi tentang Bendera, Bahasa, dan Lambang Negara serta Lagu Kebangsaan. Bab I pasal 1 ayat 2 menyebutkan bahwa "Bahasa Negara Kesatuan Republik Indonesia yang selanjutnya disebut Bahasa Indonesia adalah bahasa resmi nasional yang digunakan di seluruh wilayah Negara Kesatuan Republik Indonesia”.

\section{B. Metode Penelitian}

Penelitian ini berbentuk deskriptif eksplanatif (Moleong, 2010). Data dikumpulkan dengan menggunakan angket (Cohen, 2000). Validitas data ditempuh dengan triangulasi sumber, triangulasi metode, triangulasi peneliti, dan triangulasi teori (Moleong, 2010). Penelitian ini dilakukan dari Mei sampai Oktober 2017. Adapun populasinya adalah seluruh mahasiswa berbagai perguruan tinggi di Cirebon, baik bidang umum, agama, maritim, maupun kesehatan. Sampel penelitian adalah masingmasing satu kelas dari 38 perguruan tinggi yang ada di wilayah Cirebon.

\section{Hasil dan Pembahasan}

Seperti yang telah diuraikan di atas bahwa data pada penelitian ini dikumpulkan dengan menggunakan angket. Angket ini memuat 15 pernyataan, meliputi: 1) Saya mengakui bahwa bahasa Indonesia lebih menarik; 2) Saya menggunakan bahasa Indonesia sebagai bahasa utama dalam pembelajaran; 3) Saya merasa lebih akrab dan sopan kalau berbahasa Indonesia dengan teman sekelas untuk berdiskusi pada saat pembelajaran; 4) Saya menggunakan bahasa Indonesia untuk bertanya kepada dosen jika materi yang disampaikan kurang saya mengerti; 5) Saya menggunakan bahasa Indonesia untuk menjawab pertanyaan yang diajukan oleh dosen; 6) Saya menggunakan bahasa Indonesia untuk berdiskusi dengan teman di luar pembelajaran; 7) Saya selalu menggunakan bahasa Indonesia di luar pembelajaran; 8) Saya lebih suka menggunakan bahasa Indonesia tidak baku atau bahasa Indonesia yang santai; 9) Saya merasa, bahasa Indonesia baku terlalu sulit; 10) Saya bangga berbahasa Indonesia; 11) 
Saya percaya lama-kelamaan bahasa Indonesia dapat menggantikan bahasa asing; 12) Saya percaya bahasa Indonesia dapat eksis di dunia; 13) Saya lebih senang menggunakan bahasa Inggris; 14) Saya lebih percaya diri jika menggunakan bahasa Inggris ketika berdiskusi dengan teman-teman dari kampus lain; dan 15) Saya lebih bangga jika dapat berbahasa asing. Pilihan yang diberikan meliputi: 1) tidak pernah, 2) kadang-kadang, 3) sering, dan 4) selalu.

Berikut ini hasil 120 angket yang telah diisi dan dikembalikan oleh informan. Mayoritas informan menyatakan bahwa bahasa Indonesia menarik. Hal ini dikarenakan bahasa Indonesia merupakan bahasa identitas negara Indonesia. Oleh karena itu, sangat wajar jika semua orang Indonesia belajar bahasa Indonesia.

Sebagian besar mahasiswa menggunakan bahasa Indonesia dalam pembelajaran. Hal ini dikarenakan para pengajar juga menggunakan bahasa Indonesia. Demikian juga dengan mahasiswa lain. Rerata mahasiswa merasa malu jika tidak berbahasa Indonesia ketika proses belajar di kelas. Selain itu, fenomena ini menjadi bukti bahwa mahasiswa masih mencintai bahasa Indonesia daripada bahasa asing. Mahasiswa merasa lebih nyaman jika berdiskusi dengan menggunakan bahasa Indonesia. Hal ini karena mahasiswa tidak dari tempat atau daerah yang sama sehingga bahasa yang digunakan pun berbeda. Misalnya, mahasiswa yang berasal dari Kuningan dan Majalengka biasa menggunakan bahasa Sunda sedangkan mahasiswa yang berasal dari Cirebon dan Indramayu berbahasa Jawa. Demi menghindari ketidakmengertian dalam berdiskusi maka digunakan bahasa Indonesia.

Mahasiswa sangat menyadari peran bahasa Indonesia dalam pendidikan. Hal ini ditunjukkan dengan selalu menggunakan bahasa Indonesia saat bertanya kepada dosen. Penggunaan bahasa Indonesia memang dapat membantu dalam proses belajar di kelas. Perbedaan latar belakang budaya dan bahasa dapat diselesaikan dengan menggunakan bahasa Indonesia. Mahasiswa juga tidak perlu belajar keras untuk menguasai bahasa Indonesia karena sejak dari kecil sudah menggunakannya. Demikian juga ketika menjawab pertanyaan dosen. Mahasiswa memilih menggunakan bahasa Indonesia. Hal ini untuk menghindari ketidakmengertian jika menggunakan bahasa daerah. Bisa jadi karena dosen dan mahasiswa berasal dari wilayah yang memiliki bahasa daerah berbeda. Mahasiswa tidak ragu untuk menjawab pertanyaan dengan menggunakan 
bahasa Indonesia. Walaupun kadang unsur kedaerahan tetap muncul, tetapi itu sebatas dialek dan bukan pada kosakata yang digunakan.

Ketika berdiskusi di luar kelas, mahasiswa tidak menggunakan bahasa Indonesia. Hal ini karena diskusi dilakukan secara tidak formal dan hanya diikuti oleh beberapa orang. Penyataan ini bertautan dengan pernyataan selanjutnya. Hanya sedikit mahasiswa yang menggunakan bahasa Indonesia ketika berada di luar kelas. Rerata mahasiswa menggunakan bahasa daerah masing-masing. Hal ini untuk lebih menciptakan keakraban. Apalagi bagi para mahasiswa yang berasal dari perantauan. Penggunaan bahasa daerah dapat juga mengobati kerinduan pada kampung halaman. Telah jamak diketahui bahwa mahasiswa merupakan individu yang dinamis. Mahasiswa lebih suka menggunakan bahasa Indonesia tidak baku dikarenakan lebih santai. Bahasa Indonesia resmi mengakibatkan seperti ada jarak. Jika berbicara dengan sesama mahasiswa, bahasa santailah yang menjadi pilihan. Namun ketika berbicara dengan dosen, mahasiswa akan memilih menggunakan bahasa Indonesia formal.

Rerata mahasiswa percaya bahwa bahasa Indonesia akan tetap eksis meskipun di tengah bahasa-bahasa asing, seperti Korea, Mandarin, Jepang, Perancis, dan Spanyol. Hal ini dikarenakan pengguna bahasa Indonesia sangat besar. Seluruh warga negara Indonesia tentu saja menggunakan bahasa Indonesia dalam komunikasi sehari-hari. Walaupun tidak jarang mahasiswa juga mempelajari bahasa asing, tetapi bahasa Indonesia tetap menjadi rujukan utama.

\section{Simpulan}

Berdasarkan analisis data dapat disimpulkan bahwa mahasiswa memiliki sikap bahasa yang baik. Hal ini dibuktikan dengan pemahaman akan kaidah bahasa Indonesia yang sudah baik juga. Demikian juga pada aspek afektif. Meskipun memelajari bahasa asing, mahasiswa tetap bangga dan menggunakan bahasa Indonesia. Adapun faktorfaktor yang menyebabkan kecenderungan sikap bahasa tersebut: 1) mahasiswa menyadari peran penting bahasa Indonesia dalam pendidikan, 2) mahasiswa lebih percaya diri jika berbicara dengan menggunakan bahasa Indonesia, dan 3) mahasiswa yakin bahwa bahasa Indonesia akan tetap eksis karena banyaknya jumlah penggunanya. 


\section{Daftar Pustaka}

Badan Pengembangan dan Pembinaan Bahasa. (TT). Sekilas tentang Sejarah Bahasa Indonesia. Jakarta: Kementerian Pendidikan dan Kebudayaan Republik Indonesia diakses di http://badanbahasa.kemdikbud.go.id/lamanbahasa/petunjuk_praktis/627/Sekilas\% 20Tentang\%20Sejarah\%20Bahasa\%20Indonesia pada Minggu, 19 Februari 2017 pukul 14.32 WIB.

Chaer, Abdul dan Agustina, Leonie. (1995). Sosiolinguistik Perkenalan Awal. Rineka Cipta: Jakarta.

Cohen, Louis, et al. (2000). Research Methods in Education. Great Britain: TJ International Ltd, Padstow, Cornwall.

Gunarsa, Singgih \& Gunarsa, Yulia. (2001). Psikologi Praktis Anak, Remaja, dan Keluarga. Jakarta: Gunung Mulia.

Kridalaksana, H. (2001). Kamus Linguistik. Jakarta: Gramedia.

Moleong, Lexy. J. (2010). Metode Penelitian Kualitatif. Edisi Revisi. Bandung: Remaja Rosdakarya.

Sobara, Iwa dan Ardiyani, Dewi Kartika. (2013). "Sikap Bahasa Mahasiswa Laki-Laki dan Perempuan di Jurusan Sastra Jerman Universitas Negeri Malang' dalam Bahasa dan Seni Thn. 41, No. 1, Februari 2013, hlm. 93-105.

Wardani, K.Devi Kalfika Anggria, Gosong, M., dan Artawan, G. (2013). "Sikap Bahasa Siswa terhadap Bahasa Indonesia: Studi Kasus di SMA Negeri 1 Singaraja dalam Jurnal Program Studi Pendidikan Bahasa Dan Sastra Indonesia Universitas Pendidikan Ganesha, Vol. 2, Thn. 2013, hlm. 1-10.

Wistari, N.W., Suandi, I N., dan Wendra, I Wyn. (2015). "Sikap Bahasa Siswa Program Cambridge Dyatmika School terhadap Bahasa Indonesia" dalam Jurusan Pendidikan Bahasa dan Sastra Indonesia Universitas Pendidikan Ganesha Vol. 3, No.1 (2015), hlm. 1-13.

Yusuf, Syamsu. (2012). Psikologi Perkembangan Anak dan Remaja. Bandung: Remaja Rosdakarya. 